\title{
Small Integral Membrane Protein 24
}

National Cancer Institute

\section{Source}

National Cancer Institute. Small Integral Membrane Protein 24. NCI Thesaurus. Code C131751.

Small integral membrane protein $24(130 \mathrm{aa}, \sim 15 \mathrm{kDa})$ is encoded by the human SMIM24 gene. This protein has no known function. 